\title{
ife
}

\section{PRODUCT MARKET COMPETITION, INFORMATION AND EARNINGS MANAGEMENT}
IE Business School Working Paper
DE8-131-I
$24 / 05 / 2010$

Garen Markarian

\section{PhD Professor IE Business School garen.markarian@ie.edu}

\author{
Juan Santaló \\ $\mathrm{PhD}$ professor IE Business School \\ juan.santalo@ie.edu
}

We study the effect of product market competition on the incentives to engage in earnings manipulation and we find that they crucially depend on the level of visibility of firm real activity in the marketplace. If investors can perfectly observe real firm output and sales, then CEOs are forced to act in the marketplace in a consistent manner with the earnings they are reporting. We show in a simple model how this is too expensive in more competitive markets and therefore competition should reduce rather than increase earnings manipulation. On the contrary, if investors and analysts cannot observe firm real output in the marketplace we show how manipulating earnings might be particularly rewarding in more competitive markets since the boost in market value of good news is especially important. Using a large panel dataset, we report empirical evidence that systematically and consistently points out to a positive effect of product market competition on the level of earnings management. This has been found with three different proxies of market competition, three alternate specifications of the "Jones" earnings management model, earnings quality measures and with different econometric techniques that alleviate endogeneity concerns including firm fixed effects and controls of firm corporate governance.

Keywords: earnings management, competition, earnings quality, Cournot-Nash Duopoly 
Copyright $@ 2010$ by Garen Markarian and Juan Santaló, Professors at IE Business School.

This working paper is distributed for purposes of comment and discussion only. It may not be reproduced without permission of the copyright holders.

Printed at IE Publishing Department, Madrid. Spain. 
Since Adam Smith, mainstream Economics has argued that product market competition constitutes a superior mechanism for the efficient allocation of resources, and has a disciplining effect over rent seeking and managerial inefficiencies. Consistent with this view, recent literature has empirically shown how "good" corporate governance mechanisms are only needed when market rents can be wasted or dissipated (Giroud and Mueller, 2008, 2009). Otherwise, just pure market competition directs managers to the maximization of shareholder's wealth, without further need of any particular governance procedures or controls. Earnings manipulation has been repeatedly reported as another manifestation of managerial rent appropriation, at the expense of shareholders, when executives use earnings management for their private interest. This paper investigates the disciplinary effect of competition on earnings management arguing (and empirically finding) that product competition could increase managerial propensity to engage in earnings manipulation. As such, this study is among a select few that provide evidence regarding the undesirable effects of competition in a capital markets setting (see Cetorelli, 2001, for a thorough discussion).

We build a theoretical model that illustrates how market competition could have a dark side regarding accounting practices. This link exists because market competition induces higher punishment in the stock market when accounting earnings indicate the existence of a competitive disadvantage. However, our model has distinct implications on the sign of the competition-accounting manipulation linkage, depending on whether shareholders or stock analysts have access to real market data like individual firm output 
production. If this is the case the predicted sign of the linkage reverts and we should observe less accounting manipulation in more competitive markets.

Intuitively, when shareholders/analysts can observe firm individual output production, then managers that pretend to be running an efficient corporation not only need to manipulate accounting earnings, but also they have to operate in the real market as if they were efficient (see Bagnoli and Watts, 2007, and Kedia and Philippon, 2009). In these circumstances, the cost of misleading analysts/shareholders by producing larger levels of output is costlier in more competitive markets, and therefore, ceteris paribus managers should be less prone to manipulate earnings.

In our empirical analysis, we provide strong evidence of a positive connection between market competition and earnings management. This empirical finding is robust to the use of three distinct proxies of market competition: the Herfindhal-Hirschman industrial concentration index, number of competitors in the industry and changes in competition due to changes in import penetration as a result of exogenous differences in trade tariffs (Guadalupe and Cuñat, 2009). Our results are also robust to the use of distinct specifications of the Jones (1995) measure of earnings manipulation including the forward looking model of Dechow, Richardson and Tuma (2003). We also provide evidence that product market competition decreases earnings quality using the construct of Dechow and Dichev (2002). Furthermore, our results are invariant to control by variables related to both earnings management and competitive structure such as corporate governance, CEO pay-for-performance and the sophistication of shareholders. Finally, our findings do not vary when including firm fixed-effects that alleviate endogeneity concerns. 
This paper has several contributions. First, we identify a key determinant of earnings manipulation. Prior research has identified various firm, $\mathrm{CEO}$, and regulatory motivations for earnings management (Healy, 1985; Watts and Zimmermann, 1986; Kedia and Philippon, 2009). We contribute to this literature by showing that industrial structure, in terms of competitive intensity, affects managerial financial reporting decisions. Thus, we identify an exogenous non-firm specific factor related to earnings management, which enables us to make inferences about firm financial reporting policies by measuring the (easily observable) degree of competition faced by firms in product markets. Second, although the negative association between information transparency and earnings management is well known in the accounting literature (Dye, 1988, Kang, Palmon and Sudit, 2009, Richardson, 2000, and Trueman and Titman, 1988), we feature a novel mechanism in which information transparency decreases earnings manipulation through its impact on the marginal effect of product competition; henceforth we stress the interplay between information transparency and market competition to explain the quality of accounting practices when corporate accounting earnings are required to be consistent with firm strategies in the product market. Additionally we contribute to the corporate governance literature by showing the dark side of product market competition. Long lauded as a mechanism that increases efficiency, reduces agency costs and deters managerial slack (Baggs and Bettignies, 2007, Hart, 1983, Schmidt, 1997) this paper shows that under some conditions product market competition may exacerbate the agency problem between managers and firm owners. Given that recent findings that show that corporate governance only matters in non-competitive industries (Giroud and Mueller, 2008, 2009), we show that at least from a financial reporting perspective, proper 
governance structures could also be necessary in competitive industries. The rest of the paper is structured as follows. Section I provides a simple analytical framework to understand the relationship between market competition and earnings manipulation in two different information scenarios. Section II describes the data and variable construction. Section III discusses our empirical strategy. Section IV displays our main results. Section V contains the discussion of the robustness tests while Section VI concludes.

\section{Analytical Framework and Hypothesis Development}

In generally accepted terms, earnings management occurs "when managers use judgment in financial reporting, and in structuring transactions, to alter financial reports to either mislead some stakeholders about the underlying economic performance of the company or to influence contractual outcomes that depend on reported accounting numbers" (Healy and Wahlen, 1999, p. 368). Managers can manipulate earnings to inflate their compensation (Carter, Lynch and Zechman, 2009); benefit from insider trading gains (Kedia and Philippon, 2009) or just to camouflage straightforward appropriation like in the case of Tyco. We study the relationship between product market competition and earnings management with a simple oligopoly model with imperfect information in which variations of the market competition is driven by exogenous changes in the number of competitors ${ }^{1}$. As in Bagnoli and Watts (2007) (but opposed to previous literature about information disclosure like Darrough, 1993; Raith, 1996; Vives, 2006) in our model firms can bias the information they report. Unlike Bagnoli and Watts (2007) we do not assume

\footnotetext{
${ }^{1}$ Equivalently, we could build a more complex model with free entry in which $\mathrm{N}$ is determined endogeneously by the interplay between market size, fixed costs of production and strength of market competition as in Sutton (1991). Since our purposes is not building a fully fledged theoretical model we simply model $\mathrm{N}$ as exogenous keeping in mind that changes in $\mathrm{N}$ are driven by changes in exogenous parameters like the importance of fixed cost and economies of scale in the industry.
} 
that there is an exogenous cost of misreporting since in our model the benefits and costs of misreporting are pure agency considerations in which CEOs have private incentives to maximize short term market value.

In our setup we follow a simplified version of the Cournot model with imperfect information presented in Vives (2002). We consider $\mathrm{N}$ firms that compete in a market with a homogeneous product. There are $m$ consumers each one with a utility function $U(x)=\alpha x-\beta x^{2} / 2-p x$, where $\alpha>0 ; \beta>0 ; p$ is unit price while $x$ represents the consumption level. With these preferences, the inverse demand function is given by $P_{m}(X)=\alpha-\beta_{m} X$, where $\beta_{m}=\beta / m$ and $X$ is total output. Each firm $i$ has a cost function given by $C_{i}(x)=\theta_{i} x$; where $\theta_{i}$ can have two values with equal probability: $\theta_{H}$ or $\theta_{L}$; where $\theta_{H}>\theta_{L}>0$.

The $\mathrm{N}$ firms compete a la Cournot in two consecutive periods. $\theta_{\mathrm{i}}$ is drawn independently each period meaning that firms with high costs in period 1 may have low costs the next period. For simplicity we assume that the unit cost of production in period 2 is independent of the unit cost of production achieved in period 1. That is, we assume that $\operatorname{Prob}\left(\theta_{i}^{2} / \theta_{i}^{1}\right)=\operatorname{Prob}\left(\theta_{i}^{2}\right)=1 / 2$ where the super-index identifies the period.

We assume that risk neutral managers manipulate earnings not for achieving any strategic advantage as in Bagnoli and Watts (2007) but rather as an expression of the agency problem between managers and shareholders. We model this by assuming that managerial compensation is designed such that managers have incentives to maximize the market value of the company in period 1 at the expense of market value in period 2 . For this, we assume that managerial compensation is $w+\mu_{1} M V_{1}+\mu_{2} M V_{2}$, where $w$ represents fixed wage and $M V_{t}$ market value of the company at period $t$, the critical assumption is that $\mu_{1}=\mu_{2}+\mu$ where $\mu_{2}>0 ; \mu>0$. The fact that $\mu$ is larger than zero can be justified 
thinking that executive stock options have exercise date in period 1 or because managers want to engage in insider trading in period 1 as in Kedia and Philippon (2009). For simplicity and without loss of generality we assume that $\mu_{2}=0$. (Our results below hold whenever the difference between $\mu_{1}$ and $\mu_{2}$ is large enough).

The timeline is as follows: at the beginning of period 1 managers realize what is the cost position of their firms and firms compete a la Cournot in the marketplace knowing their unit cost but ignoring the per unit cost of their competitors. Given the above assumptions, managers try to maximize firm profits separately each period and therefore we can rely on a standard Bayesian-Cournot-Nash equilibrium to find out firm profitability at period 1 . Once competition has occurred and firm profits have materialized, managers report profit levels. This report has implications for the market value of the company since market value it is just the discounted expected sum of firm profits in both periods.

In the second period a new draw of $\theta$ is realized, and there is a growth in the number of consumers in the market respective to period 1 equal to $G, G \geq 1$. Therefore the number of consumers in period 2 is $\mathrm{m}_{2}=G m_{1}$. As in period 1, firms compete a la Cournot knowing their cost of production but ignoring rivals' costs. Once competition in the marketplace is realized in the second period, firms give to shareholders the proceedings that consist of the sum of profits achieved in both periods.

If managers manipulate earnings in period 1 and report accounting profits higher than real profits managers may get caught in the second period if the disbursements they give back to shareholders is less than what is expected. This will happen if in period 2 the cost inefficiency of a firm that has manipulated earnings has not reverted. In this case, 
when shareholders receive the proceedings of liquidation, they will discover that managers misreported earnings the previous period. They will impose a penalty $\mathrm{P}$ whenever the proceedings they receive are lower than what they expected. In contrast, if managers are lucky in period 2 and their firm gets, $\theta_{L}$, in period 2, then managers can manipulate downwards firm earnings such that the extra proceedings that firms will receive in period 2 will compensate the missing profits of period 1 . In other words, managers will not pay the penalty $\mathrm{P}$ for manipulating earnings if earnings are large enough in period 2 such that they are able to report a negative accrual in period 2 that can compensate the positive accrual in period 1 . With this we are assuming that if managers suffer a negative shock in both periods then any accounting manipulation undertaken the first period will be exposed. However, if at the second period managers are lucky and productivity increases then they will be able to hide their deception the first period even if they will be able to provide more money than what they expected. This is managers can always claim that something good happen if they give back more money than expected but they cannot claim that something bad happened if they provide less money than expected.

Next we study under what conditions managers have the incentive to manipulate earnings, given cost inefficiencies, and desires to increase first period market value. A critical assumption in the model is whether shareholders or analysts have access to information about prices and quantities in the marketplace. If they do, then a manager that wants to artificially inflate firm market value not only has to manipulate financial statements, but also has to manipulate the quantities produced and sold in the marketplace. This has implications in a Cournot-Nash equilibrium achieved as in 
Bagnoli-Watts (2007) or in Kedia-Philippon (2009). On the contrary, if shareholders/analysts have no access to price/quantity information, then managers can simply manipulate earnings with no implications in real output and price outcomes. Next we analyze the implications of the model in two different situations, focusing on the nature of the relationship between product market competition and the likelihood of earnings manipulation.

\section{a) Likelihood of earnings manipulation when shareholders/analysts do not have} access to real market information

In this case firms compete in the real market in a manner that is totally independent of any potential accounting manipulation. In both periods the Bayesian Cournot-Nash equilibrium would be achieved that we fully characterized in Appendix C. Profits of cost inefficient firms are: $\pi_{H}=\left(P(X)-\theta_{H}\right) x_{H}$ while the profits of cost efficient firms are $\pi_{L}=\left(P(X)-\theta_{L}\right) x_{L}$

In this set up, as in Kedia and Philippon (2009), we abstract from situations in which managers of efficient firms manipulate earnings to signal that they are more profitable than inefficient firms because if that type of signaling were to be available then no pooling equilibrium with accounting manipulation is possible. Yet pooling equilibrium with accounting manipulation exists as it has been systematically found in the empirical literature. We eliminate this potential signaling mechanism by assuming that shareholders/analysts distrust accounting earnings higher than the profits of the efficient firms. In other words, the off-equilibrium beliefs of shareholders/analysts are such that 
they do not assign a positive probability of being efficient to those firms that report accounting earnings higher than the profits of efficient firms.

We focus next in analyzing situations where the managers in charge of inefficient firms may want to manipulate earnings and report the same level of profits of cost efficient firms. This will happen when the gain in executive compensation surpasses the expected penalty of being caught next period. As usual in games of imperfect information two types of equilibrium can arise: a separating equilibrium in which managers running cost inefficient firms do not manipulate earnings and a pooling equilibrium in which inefficient firms report the same level of earnings as efficient firms.

\section{Separating equilibrium (equilibrium without earnings manipulation)}

The condition needed for a separating equilibrium is that managers of inefficient firms have no incentives to report superior earnings. The corresponding market values, $\operatorname{MV}_{\mathrm{i}}\left(\theta_{\mathrm{i}}\right)$, in a separating equilibrium are: $M V_{1}\left(\theta_{L}\right)=\pi_{L}+\left(\frac{1}{\mathrm{R}}\right) \mathrm{E}\left[\pi_{2}\right] ; M V_{1}\left(\theta_{H}\right)=\pi_{H}+$ $\left(\frac{1}{R}\right) E\left[\pi_{2}\right]$. This will constitute a separating equilibrium as long as managers running inefficient firms have no incentives to report profit levels corresponding to efficient firms. The benefit they would achieve is a superior compensation due to an artificially inflated market value in period 1 is $\mu\left(\pi_{L}-\pi_{H}\right)$.

However, by manipulating earnings managers may get caught next period. This will happen if in period 2 the cost inefficiency of its firm has not reverted. In this case when shareholders receive the proceedings of liquidating the firm they will discover that managers misreported earnings the previous period and therefore they will sue managers who will receive penalty $\mathrm{P}$. In contrast, if cost inefficiencies are reverted by having a lower unit cost of production, $\theta_{L}$, in period 2 , then managers can manipulate downwards 
firm earnings such that the extra proceedings that firms will receive period 2 will compensate the missing profits of period 1 . This happens because $\pi_{L}^{1}+\pi_{\mathrm{H}}^{2} \geq \pi_{H}^{1}+\pi_{\mathrm{L}}^{2}$ since $\pi_{L}^{2}=G \pi_{L}^{1} ; \pi_{H}^{2}=G \pi_{H}^{1}$ and $\pi_{L}^{i}>\pi_{H}^{i} \forall i$.

In this setup the condition for a separating equilibrium is:

Proposition 1. A separating equilibrium with no accounting manipulation is achieved as long as:

$\mu\left(\pi_{L}-\pi_{H}\right)<\left(\frac{1}{2}\right) P$

(1) simply states that managers do not misreport earnings if the increase in managerial compensation due to accounting manipulation is lower than the expected value of the penalty.

Pooling equilibrium (equilibrium with earnings manipulation):

In a pooling equilibrium cost inefficient firms will report first period profits that are equal to those reported by efficient firms. Shareholders and analysts will not be able to distinguish between low-cost and high-cost firms and as a result market value in period 1, $\dddot{M} V$, will be equal for all firms. $\dddot{M} V=\left(\frac{1}{2}\right) \pi_{L}+\left(\frac{1}{2}\right) \pi_{H}+\left(\frac{1}{\mathrm{R}}\right) \mathrm{E}\left[\pi_{2}\right]$ In this case, shareholders/analysts will underestimate the real market value of efficient firms and overestimate the market value of inefficient firms because they are unable to distinguish between them. This constitutes a pooling equilibrium as long as managers find it worthwhile to manipulate earnings. This is:

$w+\mu\left(\pi_{H}^{1}+\left(\frac{1}{R}\right) E\left[\pi_{2}\right]\right)<w+\mu\left(\frac{1}{2}\left(\pi_{L}^{1}+\pi_{H}^{1}\right)+\left(\frac{1}{R}\right) E\left[\pi_{2}\right]\right)-\left(\frac{1}{2}\right) P$

This implies: 
Proposition 2. A pooling equilibrium in which cost inefficient firms manipulate earnings is achieved as long as: $\quad P<\mu\left(\pi_{L}^{1}-\pi_{H}^{1}\right)$

Proposition 1 and Proposition 2 together imply that for given levels of $\mathrm{P}$ and $\mu$ cost inefficient firms will manipulate their earnings to look like cost efficient companies when the difference between efficient and inefficient firms is large enough, while they will not manipulate when this difference is small. Figure 1 illustrates how the likelihood of the different equilibriums varies with $\pi_{L}^{1}-\pi_{H}^{1}$.

(Insert Figure 1 about here)

Overall, the intuition of the results so far is that managers will manipulate earnings when the difference on profits between looking efficient versus inefficient is sufficiently ample. The next proposition proves that the loss of being cost inefficient is larger in more competitive markets and therefore earnings manipulating equilibriums are more likely when competition increases:

Proposition 3: When investors/analysts do not observe real market information, a pooling equilibrium in which cost inefficient firms manipulate earnings is more likely in more competitive markets.

Proposition 4: When investors/analysts do not observe real market information a separating equilibrium with no accounting manipulation is less likely in more competitive markets:

Proof of Propositions 3 and 4: See Appendix C. 
b) Likelihood of earnings manipulation when shareholders/analysts have access to real market information

As above we turn to identify the conditions needed for the existence of a pooling versus a separating equilibrium when investors observe firm activity in the real marketplace. The critical difference in this case is that if managers try to artificially inflate firm market value in period 1 not only they have to manipulate accounting earnings but they also have to change the nature of their real market actions to convince stock market analysts about their cost efficiency. As a consequence, the BayesianCournot-Nash equilibrium achieved is affected by the earning manipulation policies.

Separating equilibrium (equilibrium without earnings manipulation)

If there is no earning manipulation then the market equilibrium with imperfect information in the Bayesian-Cournot-Nash model is independent of accounting practices. As above we investigate the incentives of a manager running an inefficient firm to report earnings as if the firm was efficient to boost short term market value to increase her compensation. If a manager running an inefficient firm decides to act as if her company was efficient then her total compensation would be $w+\mu\left(\left[\tilde{P}(X)-\theta_{L}\right] X_{L}+\right.$ $\left.\left(\frac{1}{R}\right) E\left[\pi_{2}\right]\right)$; Where $\tilde{P}(X)$ represents the new lower expected market price if the manager deviates from the equilibrium, producing a larger quantity $X_{L}>X_{H}$ and it is computed by $\tilde{P}(x)=P(x)-\beta\left[X_{L}-X_{H}\right]$. Note that in this case the deviating manager will report profits of $\tilde{\pi}_{L}^{1}=\left(\widetilde{P}(X)-\theta_{L}\right) x_{L}$ while the real profits are $\pi_{L}=\left(\widetilde{P}(X)-\theta_{H}\right) x_{L}$, and therefore the total amount of earnings manipulation (accrual) would be: $\left(\theta_{H}-\theta_{L}\right) X_{L}$. 
Proposition 5: When investors/analysts observe real market information a separating equilibrium is achieved when the rate of growth of the market is large enough and:

$$
w+\mu\left(\pi_{H}^{1}+\left(\frac{1}{R}\right) E\left[\pi_{2}\right]\right)>w+\mu\left(\tilde{\pi}_{L}^{1}+\left(\frac{1}{R}\right) E\left[\pi_{2}\right]\right)-\left(\frac{1}{2}\right) P
$$

Proof. See Appendix C

Proposition 6: When stock market analysts can observe market behavior, a separating equilibrium in which cost inefficient firms do not manipulate earnings is more likely in more competitive markets.

Proof: See Appendix C.

Pooling equilibrium (equilibrium with earnings manipulation)

In this case all firms will act in the marketplace as if they were efficient independently if they really are. In a pooling equilibrium firms correctly guess that all its rivals will produce the output corresponding to efficient firms. This means that in the Bayesian-Cournot-Nash equilibrium all firms will produce output as if they were efficient. Stock market analysts will realize that they cannot differentiate between efficient and inefficient firms and all firms will have the same market value, $M V_{N D}^{P}$ :

$$
M V_{N D}^{P}=\left(\frac{1}{2}\right)\left(P(X)-\theta_{L}\right) x_{L}+\left(\frac{1}{2}\right)\left(P(X)-\theta_{H}\right) x_{L}+\frac{E[\pi]}{R}=[P(X)-\bar{\theta}] x_{L}+\frac{E[\pi]}{R}
$$

For this pooling equilibrium to hold we need that no manager has an incentive to deviate. Given the off-equilibrium beliefs defined above, we just need to check that managers running an inefficient company have no incentive to report their true earnings level. It may be the case that managers running an inefficient company have an incentive to reveal their real type to avoid the expected penalty if caught the next period. A 
deviating manager then would produce the output, $x^{*}$ from maximizing first period profits assuming that all rival will produce $x_{L}$.

The first period market value of the inefficient firm that deviates from the pooling equilibrium is then: $M V_{D}^{p e}=\left(P(X)-\beta_{m}\left(x^{*}-x_{L}\right)-\theta_{H}\right) x^{*}$.

Proposition 7: When investors/analysts do not observe real market information a pooling equilibrium is achieved when the growth rate is large enough and:

$w+\mu M V_{D}^{p e}<w+\mu M V_{N D}^{p e}-\left(\frac{1}{2}\right) P$

Proof: See Appendix C

Proposition 8: When stock market analysts can observe market behavior, a pooling equilibrium in which cost inefficient firms manipulate earnings is less likely in more competitive markets.

Proof: See Appendix C.

Overall, in the scenario in which stock analysts have access to real market information we find the exact opposite results as when they exclusively have access to accounting information. In this full information scenario earnings manipulation is less likely in more competitive markets. This happens because the gains in market value of inefficient firms that fool the market by operating as if they were efficient decreases with competition. Intuitively, competition makes more costly for inefficient companies to operate output as if they were efficient.

\section{Sample Selection and Variable Construction}

We build our sample crossing multiple sources of information. For our main results we utilize Compustat annual database to construct our earnings management variable and 
we manipulate the Compustat segment data to construct our measures of sector concentration and number of competitors. Also, we employ the CRSP monthly database to calculate share returns, and the CRSP daily database to calculate share idiosyncratic volatility. The intersection of those yields about 68,678 firm-year observations for the main analysis, over the period 1989-2006. The resulting unbalanced panel consists of 14,463 firms. For the additional analysis, we use the I/B/E/S database to calculate the number of analysts following a firm in any given year, earnings forecasts, and earnings surprises. We use the CDA/Spectrum database to calculate institutional holdings, and we employ the Bushee (1998) methodology to classify institutional investors according to their investment styles and horizons. We utilize the Institutional Shareholder Services database to calculate board independence and the IRRC database to calculate the Gompers, Ishii and Metrick (2002) anti-takeover index. Details about the sample selection are provided in Table 1.

(Insert Table 1 about here)

\section{Dependent Variables}

Our main measure of earnings management is firm-level discretionary accruals $(D A)$, calculated according the methodology of Dechow et alia(2003). Basically, discretionary accruals are calculated to be total accruals minus nondiscretionary accruals (accruals that are related to past accruals, sales growth, receivables, and property, plant, and equipment). We do an additional adjustment to factor in one year-ahead sales growth (Phillips, Pincus and Rego, 2003), and changes in cash, as per Chan et al. (2006). The calculation is done for each firm on a yearly basis adjusted for industry membership. For 
a full explanation for the calculations involved to compute earnings management please see Appendix A.

Measuring discretionary accruals is controversial and prone to error and it is not our intention to suggest a superior measure of accounting manipulation. Our results are robust to the use of distinct variants of the Jones (1991) model like the Ball and Shivakumar (2005) construct that factors in the effect of earnings conservatism, or simpler models where we do not adjust for cash holdings. In addition to our base level theoretical representation above, we also examine other earnings management proxies such as meeting/beating analyst forecasts (beating the benchmark has been identified in the literature as a strong motivation for earnings management (e.g., Burgstahler and Dichev, 1997), and the earnings quality measure of Dechow and Dichev (2002).

\section{Independent variables}

\section{Product market competition}

We construct three different market competition proxies. First we construct the Herfindahl- Hirschman Index, $H H I$, for each industry in the Fama-French classification. This is a standard index of industry concentration used profusely in the standard Industrial Organization literature that is computed by adding the square of the market share of all players operating in an industry a given year. We compute total sales in industry $i$ by considering all non-diversified companies included in Compustat, active solely in industry $i$ as well as those divisions of diversified firms that report industry $i$ as their primary sector of activity. This is the same measure of concentration used by other studies like Hou and Robinson (2006) that explore the impact of competition on stock market returns. Although we report all the results with Fama-French industries, we have 
also replicated all the analysis with competition variables measures aggregated at the four-digit NAICS level and the results are qualitatively the same.

Note that this $H H I$ is constructed using exclusively information from public companies in Compustat, and therefore it is an upwards biased estimator of the real HHI. However, it constitutes a good proxy for industry concentration since larger firms are usually public and this limits the importance of the bias. Furthermore, a large number of small local private companies may not be competing with large national or international companies even if they operate in the same NAICS code. For this reason, our in-sample concentration index might be a better proxy of the relevant extent of market competition for public companies. The only alternative would consist in using the $H H I$ reported by the US census (Ali, Klasa and Yeung, 2009). However the US census only provides concentration indexes for manufacturing industries and this data is only available one out of every five years. This would complicate the analysis with firm or industry fixed effects, which are so essential to our empirical strategy as we discuss below. Finally, we multiply the HHI by minus one to compute a variable, Competition, to facilitate the interpretation of the regression coefficients.

The number of competitors in the same industry (\#Competitors) is taken as another proxy for the intensity of competition, again using industries defined a la FamaFrench. As above, both divisions of diversified firms and non-diversified firms active in the same sector are considered as competitors. In the empirical analysis below we do not report all results with \#Competitors as independent variable to avoid flooding the paper with tables, but results are qualitatively consistent with those obtained using Competition and they are available upon request. 
For our last measure of competition we utilize measures of import penetration and industry tariff protection obtained from the John Romalis U.S. Tariff Database 1989-2001 files, the TradeStats Express National Trade Data, and the U.S. Industry Annual Accounts data section in the Bureau of Economic Analysis of the U.S. Department of Commerce as reported in $\mathrm{Xu}$ (2006). Utilizing this data, we construct measures of import penetration and industry tariff protection, covering a total of 21 manufacturing industries (3-digits NAICS level) for the period 1994-2001.

A large percentage of firms in our sample (31\%) are diversified, and as such they operate in more than one industry. The corresponding market competition proxy for these companies is constructed as the weighted average, of the market competition, in all the industries in which the company operates, where the weights are given by the percentage of firm sales in each industry.

\section{Control Variables}

We employ a number of controls in our statistical tests, based on variables identified in prior literature to be related either to earnings management or to stock price volatility. $\log M k t V a l$ denotes the logarithm of the market value of equity, used as a control for higher visibility and less information asymmetry in larger companies (Watts and Zimmerman, 1986; Bhushan, 1989)². Market competition decreases earnings and firms with lower earnings are more prone to engage in earning management practices (McNichols and Wilson, 1988; Francis, Hanna and Vincent, 1996). We ensure that lower profitability is not driving our results introducing as control variable Return on assets,

\footnotetext{
${ }^{2}$ As firm size is an important regressor, we checked for the robustness of our results given various alternate specifications of our firm size variable. We re-run our regressions using the non-logarithmic form of our size variable $(\mathrm{MktVal})$, results remain the same. We employ firm assets in lieu of the market value of equity, results are qualitatively similar. Finally, instead of $\log M k t V a l$ we employ 10 (and 40) dummies for the various size deciles, results are again unchanged.
} 
$R O A$, calculated as net income before extraordinary items divided by total assets. We also control by firm stock market returns that provide a more future oriented perspective on firm performance than accounting profits with the control variable Return, which is fiscal year stock market returns. We control for a firm's investment opportunity set and growth opportunities by calculating $M B$, which is the market value of equity divided by the book value of equity. Leverage is total debt divided by total assets, controlling for adverse selection and equity risk (Trueman and Titman,1988). We compute Volatility according to the methodology of Rajgopal and Venkatachalam (2009), which is the firm level idiosyncratic volatility, given that firm risk and earnings management decisions are related (Grant et al., 2009). Finally, we also control for year and industry effects using year and industry dummies. Other variables used in the robustness tests and other analyses are discussed in the respective sections. The definitions of the main variables are summarized in Table 2.

(Insert Table 2 around here)

Table 3 presents the descriptive statistics for the sample period, all variables winsorized at $1 \%$ and $99 \%$. We see that in our sample the absolute value of mean discretionary accruals $(D A)$ is 0.14 , while the median is 0.06 , this is due to the fact that the estimation process is noisy and yields large tails (these numbers compare well to $\mathrm{Yu}$, $2009)^{3}$. Competition, our measure of industrial competition, has a mean of -0.06 (median $=-0.05)$, while mean number of competitors per industry is 356 (median $=280)$.

\footnotetext{
${ }^{3}$ Given that the estimation of earnings management involves errors, and produces extreme tails, repeating our forthcoming multivariate analysis using ranks of this variable, or winsorization at $5 \%$ at each end, leaves results unchanged. We conclude that the distributional properties of this variable are not driving our results.
} 
Descriptive statistics of the rest of the control variables are comparable to other studies utilizing Compustat, hence are not discussed.

(Insert Table 3 about here)

Table 4 shows the Pearson correlations among our variables. We see that our measure of earnings management, $D A$, is positively and significantly related to Competition. We also see that Competition is negatively and significantly correlated with $R O A$ and negatively correlated (but no significantly) with Return suggesting that competition is indeed related to lower firm profitability. Finally, we see that earnings management is positively related to $M B$, and negatively related to $M k t v a l$, suggesting that smaller firms with higher growth opportunities manage more their earnings (see Roychowdhury, 2006).

(Insert Table 4 about here)

\section{Empirical Strategy}

As argued above, we hypothesize that a firm's competitive environment affects executive decisions to misreport firm earnings. From this perspective, we assume that earnings management of firm i at time t, EarningsManagement ${ }_{i}^{t}$, can be represented in the following linear form:

EarningsManagement $_{i}^{t}=$ Competition $_{i}^{t}+$ logmaktval $_{i}^{t}+$ ROA $_{i}^{t}+$
+ Marketobook $_{i}^{t}+$ ROA $_{i}^{t}+$ Leverage $_{i}^{t}+$ Return $_{i}^{t}+$ Volatility $_{i}^{t}+T^{t}+I_{I}+u_{i}^{t}$

Where represent $T^{t}$ year effects, $I_{I}$ represent other industry effects, the name of the control variables is self-explanatory while $u_{i}^{t}$ accounts for other remaining unobserved firm level variables. 
In our empirical analysis displayed below we run a set of linear regressions to estimate the relation between earnings management and market competition. Although we use a simultaneous specification, one could argue that the effect of competition on the incentives to manipulate earning is not contemporaneous but rather they require some time to settle in. Our results below are robust to lagging the independent variables one year.

The standard measures of earnings management used in the literature and in this paper adjust by industry membership (see Appendix A for details of how we compute our dependent variable). This practice is thought precisely to control by any industry effects that may affect earnings management practices. Given that product market competition is one industry characteristic among many, one could question whether the effects of competition could be taken into account by the usual accounting procedures that adjust by industry membership in a yearly basis. However there are two reasons that prevent standard industry adjustments to eliminate the effect of market competition on earnings management. First, consistent with the theoretical model, product market competition may not affect symmetrically all firms in the same industry. In particular only firms that have a competitive disadvantage will be those which market competition will induce to manipulate their accounting statements; while this will not be the case for firms that enjoy relative competitive superiority. These differential effects for firms competing in the same industry is what will allows us to estimate an effect of market competition on earnings management even if we adjust by industry membership. In appendix B we offer a brief mathematical illustration of this argument. Second, note that even if the proxies of market competition, Competition ${ }_{i}^{t}$, are by its nature defined at the industry-level, 
Competition $_{i}^{t}$ has firm level variability given that each diversified firm has potentially a distinct value for Competition ${ }_{i}^{t}$ and this is why our regressions are at the firm level rather than at the industry level (our results still hold if we eliminate all diversified firms and rerun our basic model)

In all our specification we additionally include industry dummies. These industry dummies represent Fama-French industries in those regressions with Competition and \#Competitors as independent variables, and we utilize three-digit NAICS codes for those regressions with Imports as proxy of market competition (We are then consistent with the industry definition used to compute each competition variable). The inclusion of industry dummies is important because of two separate reasons. First, as Nickell (1996) points out market share-based measures of market power (such as Competition) have little value when utilized in a cross-section but instead are more reliable when exploiting the explanatory power of their time variability, as we do when introducing industry dummies. Second, earnings manipulation levels may vary systematically across industries (Jones, 1991). Adding industry dummies avoids biases caused by the presence of unobserved industry characteristics that could be correlated at the same time with the intensity of earnings manipulation and market competition proxies.

We also estimate regressions with firm fixed effects to take into account generic unobserved firm heterogeneity. Note also that we cannot run regressions with industry dummies and firm fixed effects at the same time since this would require having enough number of firms that switch industries during the sample period. Besides, industry fixed effects will also capture time invariant industry effects. 
A potential drawback of our analysis is the potential endogeneity of Competition and \#Competitors and standard reverse causation arguments. In particular, it could happen that earning manipulation strategies modify market structure rather than being the result of competition in the marketplace. This could be the case if for example earnings manipulation implemented by incumbents to please shareholders and boost executive compensation makes the industry look attractive and induces entry of new competitors. . Additionally, Ali, Klasa and Yeung (2009) have criticized the use of product market competition variables measured with the Compustat dataset. Both issues are addressed by using an exogenous source of market competition as is the level of industry trade barriers. We follow Xu (2006) and Guadalupe and Cuñat (2009) using the time variation of tariffs as instruments for import penetration across three-digit NAICS manufacturing industries. As seen below, the results will not change qualitatively when employing this exogenous measure of market competition.

\section{Main Results}

Table 5 displays the results of estimating equation 7 using OLS. Given that we have a panel dataset, we adjust for having multiple observations belonging to the same firm, by clustering regressions at the firm level using Rogers (1983) standard errors. The first two columns have as a dependent variable firm level discretionary accruals computed as Dechow et al. (2003) and adjusted both for future sales growth (Phillips et al, 2003) and for changes in cash holdings (Chan et al., 2006).However our results do not change if we do not adjust for future sales growth of cash holdings or if we use the Ball and Shivakumar (2005) measure of earnings management. Column (1) has Competition as 
independent variable while column (2) has instead \#Competitors. We see that both competition variables are positively and significantly related to discretionary accruals, indicating that higher levels of competition are positively related to firm-level earnings management decisions. This shows that the preliminary evidence in the univariate correlations displayed in Table 4 is not spurious and instead it is robust to the introduction of the control variables.

Given that estimating discretionary accruals a la Jones is a noisy process and produces large outliers we windsorize the sample at 5\% from each end to make sure our results are not driven by a few discretionary accrual outliers. Column (3) of Table 5 discloses the corresponding results that again show a positive and significant association between product market competition and discretionary accruals.

Columns (4) and (5) in Table 5 investigate empirically the effect of competition for the subset of firms that manage earnings upwards, and downwards, respectively. This analysis, similar to $\mathrm{Yu}$ (2008), indicates that stronger market competition induces firms to manage earnings both upwards and downwards

The significant and positive association between product market competition and earnings management could be caused by standard omitted variable bias driven by unaccounted firm characteristics, such as unobservable CEO characteristics, regulatory structure, insider trading patterns, media scrutiny or propensity of takeover. Such unaccounted effects could drive the linkage between market competition and accounting manipulation reported previously. We address this omitted variable concern by running firm fixed-effect regressions. De facto, these regressions capture the effect of changes in firm competitive environment upon changes in firm-levels of discretionary accruals. 
Therefore, these estimations are free of any potential bias caused by any omitted firmlevel characteristic that is invariant across time. The corresponding results are displayed in column (6) of Table 5 that exhibits how the positive association between market competition and accounting manipulation is robust to the introduction of firm fixedeffects. Finally, in column 7 of Table 5, we replace our earnings management variable by utilizing the original modified Jones model as in Dechow, Sloan and Sweeney (1995), where we see that results remain unchanged.

Regarding our control variables, in almost all specification firm size (logMktval) is negatively related to earnings management, indicating that larger and more visible firms manage earnings less (see Watts and Zimmerman, 1986; Bhushan, 1989). However in the firm fixed effects specification, the coefficient turns out to be positive and significant suggesting that firms that grow in size in a given year, are more likely to increase the degree of earning manipulation. This result is consistent with evidence that indicates firms undergoing M\&As are more likely to manipulate earnings (Erickson and Wang, 1999). Additionally in all specification firms with better accounting performance, as proxied by $R O A$, are less likely to manage earnings (see $\mathrm{Yu}, 2008$, for conflicting predictions regarding the relationship between profitability and earnings management). In contrast to prior studies, the coefficient of Leverage is negative and statistically significant in six out of the seven specifications and non-significant in the remaining one, indicating that firms with higher debt levels manage earnings less. This is contrary to prior studies that find that firms manage earnings to reduce debt contracting costs (Trueman and Titman, 1988), possibly because in non-refined setting, we are unable to measure the tightness of debt covenants (however, if we eliminate our volatility measure, 
and ROA that includes interest payment on debt, the coefficient of leverage becomes positive and significant) .

Finally firms with larger growth opportunities (as proxied by $M B$ ) are more likely to manage earnings (as in $\mathrm{Yu}, 2008$, Table 5) and consistent with standard thinking lower stock market return firms and more volatile firms have a higher tendency to engage in earnings management. R-squared is $14 \%$ indicating a reasonable fit for our model.

(Insert Table 5 around here)

\section{Robustness Tests}

In this section we explore the robustness of the above reported competitionearnings manipulation linkage. First we explore whether the results hold when we control for extant corporate governance structures. Second, we examine the effect of product market competition using an alternate measure of earnings management, by utilizing the earnings quality measure of Dechow-Dichev (2002), whose estimation is distinct from Jones type models. We also utilize the likelihood of meeting and/or beating analyst's forecasts as an indirect indicator of earnings management (see Burgstahler and Dichev, 1997). Finally we investigate the impact of using arguably exogenous measures of competition like the intensity of import penetration or the level of import tariffs.

Klein (2002) provides empirical evidence that "good" governance structures are negatively related to the degree of firm earnings management. For the purpose of this study her findings are particularly important since Giroud-Mueller $(2008,2009)$ have recently shown how corporate governance seems to matter only in non-competitive industries. Hence, if we do not include controls for corporate governance it may be the case that the estimates displayed in table 5 arise from omitted variable bias given that the 
literature has shown corporate governance to be related both to earnings management and product market competition. We calculate firm governance characteristics using two separate proxies: the percentage of independent directors on the board (data obtained from Institutional Shareholder Services, ISS), and the anti-takeover index developed by Gompers et al. (2003) (data obtained from the Investor Responsibility Research Center, IRRC).

Table 6 reproduces the results of estimating our main specification controlling successively for board independence measured as the proportion of outside directors in the board, the GIM index of antitakeover protection as elaborated by Gompers et al. (2003); CEO stock options that is computed by dividing the total number of stock options divided by total shares outstanding ${ }^{4}$; turnover proxied by the number of shares traded during a fiscal year divided by the total shares outstanding, and institutional investors type according to Bushee (1998). Table 6 shows how the effect of competition on earnings managements is not affected by the introduction of any of these corporate governance control since the corresponding coefficient barely changes and it is in all specifications positive and statistical significant. Note that the only corporate governance variables that seem to affect earnings manipulation are the shares owned by the distinct institutional investor types. More particularly the percentage of shares owned by shortterm oriented institutional investors (Transient) are associated with more accounting manipulation while the percentage of shares owned by more long-term oriented institutional investors (indexer) seems to reduce earnings management. This is fully consistent with the main intuition of Bushee (1999) according to which managers are

\footnotetext{
${ }^{4}$ Using alternate measures of CEO equity holdings leaves results unchanged: we utilize a measure of CEO pay-for-performance as per Yermack (1995), or stock-option risk-taking incentives as per Rajgopal and Skinner (2003), or the dollar value of options outstanding, leaves results are unchanged.
} 
more prone to manipulate earnings when a large proportion of ownership is held by institutions that engage more profusely in momentum trading and have high portfolio turnover.

(Insert Table 6 around here)

Next we proceed to check whether our results extend to other traditionally used proxies of accounting manipulation. We first compute the Dechow-Dichev (2002) measure of earnings quality $(D D)$. The Dechow-Dichev model measures the extent to which earnings map into cash flows, for each industry/year combination, over a five year rolling window. Given that this measure is influenced by earnings quality over a five year period, we lag all our independent variables by five years. The first column of Table 7 displays the coefficient estimates of our main specification with DD as dependent variable. As before, the coefficient on Competition is positive to $D D$ and statistically significant $(\mathrm{t}=4.2, \mathrm{P}<0.01)$ suggesting that higher levels of competition lead to lower levels of earnings quality.

We also assess firm levels of earnings management by using the probability of meeting/just beating sell-side financial analyst earnings benchmarks. Intuitively, companies that just meet or beat analyst's forecasts are more likely to have engaged in earnings management that others that clearly did not meet them or surpass them (Burgstahler and Dichev, 1997). We compute MEET which is a dummy variable equals to 1 if a firm just meets or beats (by 1 cent) consensus analysts forecast ( $9 \%$ of the firms). We obtain analyst forecasts from I/B/E/S, resulting into 52,532 usable observations. The second column of Table 7 replicates our main specification (7), but with MEET as a dependent variable. Given the binary characteristic of the dependent variable, we use a 
logit regression. The displayed results show that product market competition is not related to the likelihood of meeting or just beating analysts' forecasts.Next, we construct a different dummy variable, $B E A T$, which equals one if firm reported earnings meet, or exceed, analyst forecasts ( $58 \%$ of the firms). Logit regression whose coefficient estimates are reported in column (3) of Table 7 indicate that Competition is positively related to $B E A T$ (t-statistic=2.62). This reveals an interesting pattern: firms that operate in more competitive industries are less likely to accurately meet analyst's forecasts and instead they are much more likely to exceed it. This is consistent with the main logic behind the theoretical model of section II in which competition increases the rewards of manipulating earnings and similarly of exceeding analyst's forecasts. However it is inconsistent with the standard view (Burgstahler and Dichev, 1997) in which companies manipulate earnings just to meet analyst's expectations.

Finally, we investigate how robust are the empirical outcomes when we consider measures of product market competition that are arguably exogenous like import penetration and import tariffs. The purpose of this additional analysis is to rule out the possibility that earnings management from incumbent companies induces changes in market structure rather than competition increasing the incentives to engage in manipulation of accounting statements. Additionally, this measure does not suffer the problems identified by Ali, Klasa and Yeung (2009) when using product market competition variables measured with the Compustat dataset.

As explained above this data is only available for manufacturing industries and for the period 1994-2001 and for that reason our sample size gets reduced to 19,138 firmyear observations. Columns (4) and (5) of Table 7 display the outcomes of estimating 
(10) using two separate, but related proxies of competition: import penetration, and the level of import tariffs. Note that since we include industry dummies (in this case at the three digit NAICS code level) then we are capturing the effect of changes across time of import penetration and import tariffs on earning manipulation practices. The last two columns of Table 7 show how more import penetration (more competition) is associated with more earnings management ( $\mathrm{t}$-statistic $=1.93, \mathrm{P}<0.05$ ), while larger import tariffs (less competition) are associated to lower levels of earnings manipulation (t-statistic=5.84, $\mathrm{P}<0.01$ ), supporting once more the previous results that competition and earnings management are positively associated.

( Insert Table 7 around here)

\section{Conclusions}

The empirical evidence reported above systematically and consistently points out to a positive effect of product market competition on the level of earnings management. This has been found with four different measures of earnings management, three different proxies of market competition, with different econometric techniques that alleviate endogeneity concerns and controlling by multiple variables that could be correlated at the same time with competition and earning management practices. These robust empirical findings contrast with the implications of the theoretical model in which the effect of competition on earnings manipulation crucially depended on the level of visibility for analysts of investors of firm output in the marketplace. If investors can observe real firm output and sales, then CEOs that want to manipulate firm earnings to pursue their own private interest are forced to act in the marketplace in a consistent manner with the earnings they are reporting. The theoretical section shows how this is too expensive in 
more competitive markets and therefore competition should reduce rather than increase earnings manipulation. On the contrary, if investors and analysts cannot observe firm real output in the marketplace then manipulating earnings might be particularly tempting in more competitive markets since the amplifying effect in market value of good news is especially important in more competitive markets.

Overall, since we consistently and systematically find in the data a positive association between competition and earnings manipulation then the evidence consistent with a world in which investors and analysts cannot observe directly what is happening in the marketplace in terms of firm output and prices. This is not entirely surprising since if investors could perfectly observe firm output and prices then the information content of accounting statements would be quite limited and the corresponding impact of accounting on the stock market almost null and this blatantly contradicts extant evidence. Yet, it could be the case that in some industries the visibility of individual firm output and prices is much larger than in others and accordingly the nature of the competition-manipulation linkage could be heterogeneous across industries. This possibility should be investigated by future research. 


\section{References}

Ali, A., Klasa, S, and E. Yeung. 2009. The limitations of industry concentration measures constructed with Compustat data: Implications for finance research. Review of Financial Studies, 22: 3839-3871.

Baggs, J. and J. Bettignies. 2007. Product Market Competition and Agency Costs. Journal of Industrial Economics 55(2): 289-323, 06.

Bagnoli, M., Watts, S. 2007. Oligopoly, Disclosure and Earnings Management”. Working paper.

Ball, R. and L. Shivakumar. 2005. Earnings quality in UK private firms: comparative loss recognition timeliness. Journal of Accounting and Economics, 39(1): 83-128.

Bhushan, R. 1989. Firm characteristics and analyst following, Journal of Accounting and Economics 11(2-3): 255-274.

Burgstahler, D. and I. Dichev. 1997. Earnings management to avoid earnings decreases and losses. Journal of Accounting and Economics 24 (1): 99-126.

Bushee, B. 1998. The influence of institutional investors on myopic R\&D investment behaviour. The Accounting Review 73(3): 305-333.

Carter, M.E., Lynch. L., Zechman, S. 2009. Change in bonus contracts in the postSarbanes-Oxley era. Review of Accounting Studies 14(4): 480-506.

Cetorelli, N.2001. Bank Competition: Good or Bad? Economic Perspectives: 38-48.

Chan, K., C. Chan, N. Jegadeesh, and J. Lakonishok (2006): Earnings quality and stock returns. The Journal of Business 79 (3): 1041-1082.

Darrough, M. 1993, 'Disclosure policy and competition: Cournot vs. Bertrand', Accounting Review 68: 534-61.

Dechow, P., R. Sloan, and A. Sweeney. 1995. Detecting earnings management. The Accounting Review 70 (2): 193-225.

Dechow, P. and I. Dichev. 2002. The quality of accruals and earnings: The role of accrual estimation errors. The Accounting Review 77 (Supplement): 35-59.

Dechow, P., S. Richardson, and I. Tuna. 2003. Why Are Earnings Kinky? An Examination of the Earnings Management Explanation. Review of Accounting Studies 8: 355-384.

Dye, R.1988. Earnings Management in an Overlapping Generations Model." Journal of Accounting Research 26: 195-235.

Erickson, M., W., Shiing-wu. 1999. Earnings management by acquiring firms in stock for stock mergers. Journal of Accounting and Economics, vol. 27(2): 149-176.

Francis, J., Hanna D., L.Vincent. 1996 . Causes and Effects of Discretionary Asset Write-Offs. Journal of Accounting Research 34, 117-134.

Hou, K., and D.T. Robinson. 2006. Industry Concentration and Average Stock Returns, Journal of Finance, 61: 1927-1956

Giroud, X., Mueller H. 2008. Corporate Governance, Product Market Competition, and Equity Prices. ECGI - Finance Working Paper No. 219/2008.

Giroud, X., Mueller H. 2009. Does Corporate Governance Matter in Competitive Industries? Forthcoming at the Journal of Financial Economics.

Gompers, P., Ishii, J.L., A. Metrick, 2003. Corporate Governance and Equity Prices. Quarterly Journal of Economics 118 (1): 107-155. 
Guadalupe, M., Cunyat, V. 2009. Globalization and the Provision of Incentives Inside the Firm. Forthcoming at the Journal of Labor Economics.

Hart, O. 1983. The Market as an Incentive Mechanism. Bell Journal of Economics 14: 366-382.

Healy, P. and Wahlen, J. 1999. A review of the creative accounting literature and its implications for standard setting. Accounting Horizons 13 (4): 365-383.

Healy, P. 1985. The Effect of Bonus Schemes on Accounting Decisions, Journal of Accounting and Economics, 7 (4): 85-107.

Jones, J. J. 1991. Earnings Management During Import Relief Investigations. Journal of Accounting Research 29(2): 193-228.

Kang, P., Palmon, D., Sudit, E. 2009. Firms' Information Environment and Earnings Management. Working paper available at SSRN: http://ssrn.com/abstract=1465244.

Kedia, S., Philippon, T. 2009. The Economics of Fraudulent Accounting. The Review of Financial Studies, Vol. 22 (6) pp. 2169-2199.

Klein, A. 2002. Audit committee, board of director characteristics, and earnings management. Journal of Accounting and Economics, 33 (3): 375-400.

McNichols, M., P. Wilson. 1988. Evidence of Earnings Management from the Provision for Bad Debts. Journal of Accounting Research 26: 1-31.

Nickell, S., 1996. Competition and Corporate Performance. The Journal of Political Economy 104(4): 724-746.

Phillips, J.,Pincus, M. and S. Rego. 2003. Earnings management: New evidence based on deferred tax expense. The Accounting Review 78 (2): 491-521.

Raith. 1996. A General Model of Information Sharing in Oligopoly. Journal of Economic Theory 71(1): 260-288.

Rajgopal, S., M. Venkatachalam. 2009. Is PIN Priced? Working paper, Fuqua School of Business, Duke University.

Richardson, V. 2000. Information Asymmetry and Earnings Management: Some Evidence. Review of Quantitative Finance and Accounting, 15: 325-347.

Rogers, W., 1983. Analyzing complex survey data. Rand Corporation memorandum, Santa Monica, CA.

Roychowdhury, S. 2006. Earnings management through real activities manipulation. Journal of Accounting and Economics 42 (3): 335-370.

Schmidt, K.1997. Managerial Incentives and Product Market Competition. Review of Economic Studies 64: 191-213

Sutton, J. 1991. Sunk Costs and Market Structure, MA: M.I.T. Press.

Trueman, B., S. Titman. 1988. An explanation for accounting income smoothing. Journal of Accounting Research 26 (Supplement 3): 127-139.

Vives, X. 2002. Private Information, Strategic Behavior and Efficiency in Cournot Markets. Rand Journal of Economics 33 (3): 361-376.

Vives, X. 2006. Information Sharing Among Firms. Working Paper IESE, University of Navarra.

Watts, R., J. Zimmermann. 1986. Positive Accounting Theory. Prentice-Hall.

$\mathrm{Xu}$, J. 2006. What Determines Capital Structure? Evidence from Import Competition. GSB University of Chicago Working Paper.

$\mathrm{Yu}$, F. 2008. Analyst Coverage and Earnings Management, Journal of Financial Economics 88: 245-271. 


\section{Appendix A \\ Computation of Earnings Management}

Measuring discretionary accruals

Consistent with prior studies, discretionary accruals is measured by using the modified Jones model (Dechow et al. 1995), ${ }^{5}$ adjusted for the forward-looking model which factors in the expected increase in credit sales and one year ahead sales growth (Dechow et al., 2003; Phillips et al., 2003), and for cash holdings as per Chan et al (2001). A firm's net income is composed of cash flow from operations and total accruals. Total accruals in turn are decomposed to discretionary and non-discretionary accruals, the discretionary portion is the part which is proxied by calculations following the work of Jones (1991). Total accruals are calculated as net income minus cash flow from operations. The following cross-sectional industry-specific regression is used to "predict" the level of non-discretionary accruals (NDA) from changes in revenue. ${ }^{6}$

$$
\mathrm{TA}_{\mathrm{t}} / \mathrm{A}_{\mathrm{t}-1}=\alpha / \mathrm{A}_{\mathrm{t}-1}+\beta_{1}\left(\Delta \mathrm{REV}_{\mathrm{t}} / \mathrm{A}_{\mathrm{t}-1}\right)+\varepsilon_{\mathrm{t}}
$$

Where $\mathrm{TA}=$ total accruals, $\mathrm{A}=$ lagged total assets, and $\triangle \mathrm{REV}=$ change in revenue from year to year. Nondiscretionary accruals (scaled by assets), NDA, signifies the part of accruals which is dictated by firm sales growth, and is regarded as outside managerial control. It is calculated using the regression coefficients from equation (1):

$$
\mathrm{NDA}_{t} / \mathrm{A}_{\mathrm{t}-1}=\alpha / \mathrm{A}_{\mathrm{t}-1}+\beta_{1}\left(\Delta \mathrm{REV}_{\mathrm{t}} / \mathrm{A}_{\mathrm{t}-1}-\Delta \mathrm{REC}_{\mathrm{t}} / \mathrm{A}_{\mathrm{t}-1}\right)
$$

We do two adjustments, the first one is the factor in expected increase in credit sales and one year ahead sales growth, by estimating the following model:

$\mathrm{NDA}_{t} / \mathrm{A}_{\mathrm{t}-1}=\alpha / \mathrm{A}_{\mathrm{t}-1}+\beta_{1}\left((1+\mathrm{K}) \Delta \mathrm{REV}_{\mathrm{t}} / \mathrm{A}_{\mathrm{t}-1}-\Delta \mathrm{REC}_{\mathrm{t}} / \mathrm{A}_{\mathrm{t}-1}\right)+$ Sales_GR $\mathrm{G}_{\mathrm{t}+1} / \mathrm{A}_{\mathrm{t}-1}$

Where $\mathrm{K}$ in this regression captures the expected change in accounts receivable for a given change in sales, and Sales_Gr is the one year-ahead growth in sales. We additionally adjust for cash holdings as follows (scaling by assets is suppressed):

$\mathrm{NDA}_{t} / \mathrm{A}_{\mathrm{t}-1}=\alpha /+\beta_{1}\left((1+\mathrm{K}) \Delta \mathrm{REV}_{\mathrm{t}}-\Delta \mathrm{REC}_{\mathrm{t}}\right)+\Delta \mathrm{Cash}_{\mathrm{t}}+$ Sales_GR $_{\mathrm{t}+1}$

Finally, the non-discretionary portion of accruals is subtracted from current accruals to get the discretionary accruals:

$$
\mathrm{DA}_{\mathrm{t}}=\mathrm{Acc}_{\mathrm{t}} / \mathrm{A}_{\mathrm{t}-1}-\mathrm{NDA}_{\mathrm{t}}
$$

\footnotetext{
${ }^{5}$ In the interest of saving space we explain the discretionary accrual calculation method with brevity. For a lengthier explanation, please see Dechow et al (1995), or Philips et al. (2003).

${ }^{6}$ To preserve the stability of the estimates, we omit any industry that has less than 9 observations with full data during any given year, our results are robust across various definitions of industry, including 2 digit SICs, or Fama-French 48 industry specifications.
} 


\section{Appendix B}

\section{Mathematical example of how adjusting discretionary accruals by industry membership is not enough to account for the effect of market competition}

Usual measures of earnings management are proxied by measures of discretionary accruals adjusted by industry membership with the aim of eliminating any industry effects that may affect earnings management practices. Given that product market competition is an industry characteristic among many, one could think that any effect of market competition on earnings management should already be accounted for when using standard measures of discretionary accruals a la Jones. Nevertheless, we show in this appendix how the effect of market competition is not captured by the usual accounting procedures that adjust discretionary accruals by industry membership.

According to the theoretical model presented in the main body of the text, when analysts do not have access to real market information, the relation between first period discretionary accruals and competition can be written in the following manner: Accruals $_{i}=D_{i}\left(\pi_{L}-\pi_{H}\right)$ where $D_{i}=1$ if $\theta_{i}=\theta_{H}$ and $D_{i}=0$ if $\theta_{i}=\theta_{L}$ that can be written as:

$$
\text { Accruals }_{i}=D_{i} f(N)
$$

Hence, the average of industry accruals, using the same distributional assumptions of $\theta$ as in the text, is:

$$
\overline{\text { Accruals }}=\frac{1}{2} f(N)
$$

Subtracting $B 2$, the industry average, from $B 1$ we get

$$
\text { Accruals }_{i}-\overline{\text { Accruals }}=\left(D_{i}-\frac{1}{2}\right) f(N)
$$

$B 3$ illustrates how adjusting by industry membership is not sufficient to eliminate the effect of market competition on discretionary accruals if the effect of competition affects asymmetrically companies that operate in the same industry.More generally we can write: Accruals $_{i}=\alpha_{0}+\alpha_{1}$ Competition $_{I}+\alpha_{2}$ Competition $_{I} D_{i}+\beta X_{i}$

where $\mathrm{X}$ represent all other firm characteristics that may affect the propensity to engage in earnings management practices. The industry average would be:

$$
\overline{\text { Accruals }_{I}}=\alpha_{0}+\alpha_{1} \text { Competition }_{I} \overline{D_{I}}+\beta \bar{X}_{I}
$$

Where $\overline{\text { Accruals }_{I}}, \overline{D_{I}}, \bar{X}_{I}$ represent industry averages.

If we adjust by industry membership and we subtract (B5) from (B4) we get:

$$
\text { Accruals }_{i}-\overline{\text { Accruals }_{I}}=\alpha_{2} \text { Competition }_{I}\left(D_{i}-\overline{D_{I}}\right)+\beta\left(X_{i}-\overline{X_{I}}\right)
$$

B6 again shows that the effect of competition on earnings management is not accounted when we adjust by industry averages. 


\section{Appendix C \\ Mathematical proofs}

Proof of Propositions 3 and 4: The Bayesian-Cournot-Nash equilibrium as in Vives (2002) represents that cost inefficient firms produce $x_{H}^{t}, x_{H}^{t}=b_{n}^{t}(\alpha-\bar{\theta})-a_{n}^{t}\left(\theta_{H}-\bar{\theta}\right)$ and cost efficient firms produce $x_{L}^{t}, x_{L}^{t}=b_{n}^{t}(\alpha-\bar{\theta})-a_{n}^{t}\left(\theta_{L}-\bar{\theta}\right)$ with $a_{n}=\left(2 \beta_{m}^{t}\right)^{-1}$, $b_{n}=\left((1+N) \beta_{m}^{t}\right)^{-1}, \bar{\theta}=\left(\frac{1}{2}\right)\left(\theta_{H}+\theta_{L}\right)$ and $t=1,2$ denotes period.

With this description of the equilibrium, and assuming we are not in a monopoly scenario then (3) is more likely to be fulfilled for larger $N$ since:

$$
\begin{array}{r}
\frac{\partial\left(\pi_{L}^{1}-\pi_{H}^{1}\right)}{\partial N}=\frac{\delta b_{n}}{\delta N} \theta_{H}(\alpha-\bar{\theta})-\frac{\delta b_{n}}{\delta N} \theta_{L}(\alpha-\bar{\theta})+\left(\theta_{H}-\theta_{L}\right) a_{n} \frac{\partial P(X)}{\partial N}= \\
=\frac{\delta b_{n}}{\delta N}(\alpha-\bar{\theta})\left(\theta_{H}-\theta_{L}\right)\left[1-a_{n} \beta_{m} N\right]
\end{array}
$$

And

$\frac{\delta b_{n}}{\delta N}<0 ;(\alpha-\bar{\theta})>0 ;\left(\theta_{H}-\theta_{L}\right)>0$; then $\frac{\partial\left(\pi_{L}^{1}-\pi_{H}^{1}\right)}{\partial N} \geq 0$ when $\left[1-a_{n} \beta_{m} N\right] \leq 0$ that happens $\forall N \geq 2$.

Proof of Proposition 5: With the assumptions in the model a manager may find it convenient to mislead about the real competitive position of her company only when there is a chance that their behavior will pass unnoticed. Under these circumstances, a cheating manager that reduces costs in the second period will disburse the following to shareholders:

$$
\left[\tilde{P}(X)-\theta_{H}\right] X_{L}^{1}+\left[P_{2}(X)-\theta_{L}\right] X_{H}^{2}
$$

where note that in the second period the manager is acting as if the company was inefficient, while in fact it is efficient in order to boost market value and consequently her compensation.

Shareholders were expecting:

$$
\left[\tilde{P}(X)-\theta_{L}\right] X_{L}^{1}+\left[P_{2}(X)-\theta_{H}\right] X_{H}^{2}
$$

The difference of (c2) minus (c1) is $\left[\theta_{H}-\theta_{L}\right]\left[X_{H}^{2}-X_{L}^{1}\right]$. Therefore shareholders will only receive what they are expecting or more when $X_{H}^{2} \geq X_{L}^{1}$. This implies that if the rate of market growth $\mathrm{G}$ is not large enough then a separating equilibrium is always achieved and earnings manipulation is not possible ${ }^{7}$, the rest is straightforward. :

Proof of Proposition 6: Note that (4) is satisfied if:

$\frac{1}{2} P>\mu\left[X_{L}-X_{H}\right]\left[P(X)-\theta_{H}-\beta_{m}\right]$

From (c3) note that $\left[X_{L}-X_{H}\right]$ is independent of $\mathrm{N}$ but $\mathrm{P}(\mathrm{X})$ decreases with $\mathrm{N}$ therefore the left hand side of $(\mathrm{c} 3)$ decreases with $\mathrm{N}$ rendering a separating equilibrium more likely with no earnings manipulation in more competitive markets.

\footnotetext{
${ }^{7}$ Also one may think that by getting more money than expected, shareholders can infer that executives bias earnings downwards in the first period. We are ruling that out by assuming that penalty $\mathrm{P}$ is only paid if shareholders receive less than what they expect. Alternatively we can assume that $G=X_{L}^{1} / X_{H}^{1}$. With this assumption $X_{H}^{2}=X_{L}^{1}$ and shareholders get the second period exactly the proceeds that they are expecting.
} 


\section{Proof of Proposition 7:}

In the second period managers that have manipulated earnings will get caught if they are unable to reduce costs and once more their firms have $\theta_{H}$ as a unit cost of production. However if their firms obtain a low cost of production then they will act as if they are inefficient in order to surprise shareholders by more than expected disbursements. The amount of money that the shareholders will receive at the end of period 2 will be: $\left[P^{1}(X)-\theta_{H}\right) x_{L}^{1}+\left[P^{2}(X)-\theta_{L}\right] x_{H}^{2}$ while they were expecting $\left[P^{1}(X)-\theta_{L}\right) x_{L}^{1}+$ $\left[P^{2}(X)-\theta_{H}\right] x_{H}^{2}$. This implies that they will receive more resources than what they were expecting if $x_{H}^{2}>x_{L}^{1}$. That only happens if $\mathrm{G}$ is large enough. The derivation of (6) is straightforward.

\section{Proof of Proposition 8:}

First note that $x^{*}=\operatorname{argmax}\left\{\left(\alpha-\beta_{m}[N-1] x_{L}-\beta_{m} x-\theta_{H}\right) x\right.$ that solving the first order conditions provide $x^{*}$,

$x^{*}=\frac{\alpha-\beta_{m}[N-1] x_{L}-\theta_{H}}{2 \beta_{m}}$

Manipulating (6) we get that a pooling equilibrium will happen if $\left(\frac{1}{2}\right)\left(\frac{p}{\mu}\right)<M V_{N D}^{p e}-$ $M V_{D}^{p e}$.

And Proposition (8) holds since $\frac{\partial\left(M V_{N D}^{p e}-M V_{D}^{p e}\right)}{\partial N}<0$ because:

$M V_{N D}^{p e}-M V_{D}^{p e}=\left[\alpha-\beta_{m}\left(N x_{L}+x^{*}\right)\right]\left(x_{L}-x^{*}\right)-\bar{\theta} x_{L}+\theta_{H} x^{*}$

substitute $x^{*}$ and $x_{L}$ in $\mathrm{c} 4$ to find $M V_{N D}^{p e}-M V_{D}^{p e}=\left[\alpha-\frac{\alpha-\theta_{L}}{2}-\frac{\alpha-\theta_{H}}{2}\right]\left[\frac{\alpha-\theta_{L}}{2 \beta_{m}}-\frac{\alpha-\theta_{H}}{2 \beta_{m}}\right]+$ $\theta_{H} \frac{\alpha-\theta_{H}}{2 \beta_{m}}-\frac{\alpha-\theta_{L}}{(N+1) \beta_{m}}\left[\frac{\theta_{L}+\theta_{H} N}{2}\right]$.

From this, $\frac{\partial\left(M V_{N D}^{p e}-M V_{D}^{p e}\right)}{\partial N}=-\frac{\alpha-\theta_{L}}{2 \beta_{m}} \frac{\theta_{H}-\theta_{L}}{(N+1)^{2}}<0$ q.e.d. 


\section{Table 1: Sample Selection}

Complete Compustat annual data for sample period

Intersection with

Compustat data to calculate Earnings Management

Intersection with CRSP and full set of control variables

Base sample

68,679

Subsamples for various analyses:

Sample with $\mathrm{I} / \mathrm{B} / \mathrm{E} / \mathrm{S}$ data

Sample with Import/Tariff data

19,138

Sample with Governance data (B.Independence/Gompers)

Sample with PIN

49,073

Sample with Public

31,828

Sample with

15,370 


\section{Table 2: Select Variable Definitions}

\section{$\underline{\text { Research Variables }}$}

Competition $=$ Herfindahl-Hirschman concentration index in a given year multiplied by minus one. The index is computed taking into account sales of independent companies that report operation in that industry as well as sales of divisions -belonging to diversified companies- active in the same sector.

\#Competitors $=$ Number of competitors in the industry in a given year including all independent companies that report operation in that industry as well as divisions -belonging to diversified companies- active in the same sector.

$D A=\quad$ The absolute value of discretionary accruals calculated according to the forward model of Dechow et al.(2003), additionally adjusted for changes in cash according to Chan et al. (2002). Please see Appendix A for detailed calculations.

PIN The probability of informed trade, used as a proxy for stock price informativeness.

Public Public company activity as a percentage of total industrial output, used as a measure of public information availability.

\section{Control Variables:}

$\log M k t v a l=$ Logarithm of the market value of equity.

$R O A=$ Net income before extraordinary items divided by total assets.

$M B \quad=$ Market value of equity divided by the book value.

Leverage $=$ Long-term debt over equity.

Return $=$ Raw share returns over the prior calendar year

Volatility $=$ Idiosyncratic volatility, estimated for each firm and year as the annual average of monthly variance of daily market-adjusted returns. Daily market-adjusted returns are the excess of daily stock return for the corresponding firm over the daily return on the value weighted market portfolio. 


\section{Table 3: Descriptive Statistics of Main Variables}

$D A$ denotes the absolute value of discretionary accruals calculated according to the modified Jones model, adjusted for the forward looking model of Dechow et al.(2003), adjusted for changes in cash according to Chan et al. (2002). Competition is the Herfindhal- Hirschman index of industry concentration multiplied by minus one. \#Competitors represents the number of competitors active in the same industry. PIN is the probability of informed trade, used as a proxy for stock price informativeness. Public is public company activity as a percentage of total industrial output. Mktval is the market value of equity. ROA is net income before extra-ordinary items divided by assets. Return denotes calendar year raw share returns. Leverage is firm total debt divided by the book value of assets. Volatility is firm-level idiosyncratic volatility. $M B$ is the market value of equity divided by the book value. The time period is 1989-2006, all variables are winsorized at $1 \%$ at each end.

\begin{tabular}{lcccccc}
\hline Variable & $\mathbf{N}$ & Mean & Median & St. Dev. & P25 & P75 \\
\hline DA & 68679 & 0.148 & 0.065 & 0.222 & 0.026 & 0.155 \\
Competition & 68679 & -0.068 & -0.051 & 0.055 & -0.076 & -0.037 \\
\#Competitors & 68679 & 356.084 & 280 & 327.491 & 145 & 421 \\
MktVal & 68679 & 1140.929 & 129.877 & 3158.486 & 32.167 & 632.392 \\
ROA & 68679 & -0.032 & 0.033 & 0.239 & -0.028 & 0.072 \\
Return & 68679 & 0.162 & 0.045 & 0.683 & -0.248 & 0.375 \\
Leverage & 68679 & 0.232 & 0.205 & 0.205 & 0.042 & 0.361 \\
Volatility & 68679 & 0.047 & 0.025 & 0.064 & 0.011 & 0.054 \\
MB & 68679 & 2.721 & 1.779 & 4.025 & 1.044 & 3.149 \\
\hline
\end{tabular}




\section{Table 4: Pearson Correlations}

$D A$ denotes the absolute value of discretionary accruals calculated according to the modified Jones model, adjusted for the forward looking model of Dechow et al.(2003), adjusted for changes in cash according to Chan et al. (2002). Competition is the Herfindhal- Hirschman index of industry concentration multiplied by minus one.. Mktval is the market value of equity. ROA is net income before extra-ordinary items divided by assets. Volatility is firm-level idiosyncratic volatility. $M B$ is the market value of equity divided by the book value. Return is one year raw share returns. Leverage is long term debt over assets. The time period is 1989-2006, all variables are winsorized at $1 \%$ at each end. All correlations that are significant at the $5 \%$ level or less, are presented in bold.

\begin{tabular}{l|ccccccc}
\hline \multicolumn{1}{c}{} & DA & Competition & MktVal & ROA & Volatility & MB & Return \\
\hline Competition & $\mathbf{0 . 0 3 4 4}$ & & & & & \\
MktVal & $\mathbf{- 0 . 0 2 6 7}$ & $\mathbf{0 . 0 2 8 2}$ & & & & & \\
ROA & $\mathbf{- 0 . 2 5 6 3}$ & $\mathbf{- 0 . 0 3 5 2}$ & $\mathbf{0 . 1 2 6 2}$ & & & & \\
Volatility & $\mathbf{0 . 2 0 0 4}$ & $\mathbf{- 0 . 0 1 9 4}$ & $\mathbf{- 0 . 1 7 3 6}$ & $\mathbf{- 0 . 4 1 4 2}$ & & \\
MB & $\mathbf{0 . 1 0 7 4}$ & 0.0085 & $\mathbf{0 . 1 5 3 9}$ & $\mathbf{- 0 . 1 0 2 2}$ & $\mathbf{0 . 0 0 5 8}$ & & \\
Return & $\mathbf{0 . 0 0 7 7}$ & -0.0064 & $\mathbf{0 . 0 5 4 2}$ & $\mathbf{0 . 2 0 7 7}$ & $\mathbf{- 0 . 0 7 2 7}$ & $\mathbf{0 . 2 3 2 1}$ & \\
Leverage & $\mathbf{- 0 . 1 2 4 9}$ & -0.0026 & $\mathbf{0 . 0 1 1 1}$ & $\mathbf{- 0 . 0 3 0 1}$ & $\mathbf{0 . 0 2 7 7}$ & $\mathbf{- 0 . 1 1 9 2}$ & $\mathbf{- 0 . 0 7 7 1}$
\end{tabular}




\section{Table 5: Regression Analysis Examining the Relationship between Competition and Earnings Management}

Models (1) and (2) depict the base level models with alternate measures of competition. Model (3) utilizes the same Dependent variable but winsorized at 5\% at each end. Model (4) and (5) is for the subset of firms with positive and negative discretionary accruals, respectively. Model (6) utilizes a firm fixedeffects regression. $D A$ denotes the absolute value of discretionary accruals calculated according to the modified Jones model, adjusted for the forward looking model of Dechow et al.(2003), adjusted for changes in cash according to Chan et al. (2002). DA2 denotes the absolute value of discretionary accruals calculated according to the original modified Jones model As in Dechow et al. (1995). Competition is the Herfindhal- Hirschman index of industry concentration multiplied by minus one. \#Competitors represents the number of competitors active in the same industry. Mktval is the market value of equity. ROA is net income before extra-ordinary items divided by assets. Return denotes calendar year raw share returns. Leverage is firm total debt divided by the book value of assets. Volatility is firm-level idiosyncratic volatility. $M B$ is the market value of equity divided by the book value. The time period is $1989-2006$, all variables are winsorized at $1 \%$ at each end. $* * *, * *, *$ signify significance levels at $1 \%, 5 \%$, and $10 \%$, respectively

\begin{tabular}{|c|c|c|c|c|c|c|c|}
\hline VARIABLES & $\begin{array}{l}(1) \\
D A \\
\end{array}$ & $\begin{array}{l}(2) \\
D A \\
\end{array}$ & $\begin{array}{l}\text { (3) } \\
\text { DA }\end{array}$ & $\begin{array}{l}(4) \\
\text { DA }\end{array}$ & $\begin{array}{l}(5) \\
D A \\
\end{array}$ & $\begin{array}{l}(6) \\
\text { DA } \\
\end{array}$ & $\begin{array}{c}(7) \\
\text { DA2 }\end{array}$ \\
\hline Constant & $\begin{array}{c}0.105 * * * \\
{[3.122]}\end{array}$ & $\begin{array}{c}0.044 \\
{[1.377]}\end{array}$ & $\begin{array}{c}0.093 * * * \\
{[3.288]}\end{array}$ & $\begin{array}{c}0.107 * * \\
{[2.410]}\end{array}$ & $\begin{array}{c}-0.019 \\
{[-0.688]}\end{array}$ & $\begin{array}{c}-0.066 \\
{[-0.302]}\end{array}$ & $\begin{array}{c}0.058 * * * \\
{[3.109]}\end{array}$ \\
\hline Competition & $\begin{array}{c}0.290 * * * \\
{[7.501]}\end{array}$ & & $\begin{array}{c}0.195 * * * \\
{[6.355]}\end{array}$ & $\begin{array}{c}0.247 * * * \\
{[4.809]}\end{array}$ & $\begin{array}{c}0.331 * * * \\
{[6.675]}\end{array}$ & $\begin{array}{c}0.126^{* * *} \\
{[3.234]}\end{array}$ & $\begin{array}{c}0.128 * * * \\
{[4.780]}\end{array}$ \\
\hline \#Competitors & & $\begin{array}{c}3.1 \mathrm{e}^{-4 * * *} \\
{[27.15]}\end{array}$ & & & & & \\
\hline Return & $\begin{array}{c}0.021 * * * \\
{[14.31]}\end{array}$ & $\begin{array}{c}0.021 * * * \\
{[14.37]}\end{array}$ & $\begin{array}{c}0.017 * * * \\
{[14.98]}\end{array}$ & $\begin{array}{c}0.020 * * * \\
{[9.422]}\end{array}$ & $\begin{array}{c}0.021 * * * \\
{[9.906]}\end{array}$ & $\begin{array}{c}0.016^{* * *} \\
{[12.37]}\end{array}$ & $\begin{array}{c}0.023 * * * \\
{[17.57]}\end{array}$ \\
\hline Volatility & $\begin{array}{c}0.192 * * * \\
{[10.06]} \\
-\end{array}$ & $\begin{array}{c}0.158 * * * \\
{[8.479]}\end{array}$ & $\begin{array}{c}0.146^{* * *} \\
{[10.14]}\end{array}$ & $\begin{array}{c}0.253 * * * \\
{[8.706]}\end{array}$ & $\begin{array}{c}0.173 * * * \\
{[7.205]}\end{array}$ & $\begin{array}{c}0.159 * * * \\
{[8.418]}\end{array}$ & $\begin{array}{c}0.114 * * * \\
{[7.490]}\end{array}$ \\
\hline logMktVal & $\begin{array}{c}0.003 * * * \\
{[-6.322]}\end{array}$ & $\begin{array}{c}-0.004 * * * \\
{[-8.652]}\end{array}$ & $\begin{array}{c}-0.003 * * * \\
{[-8.539]}\end{array}$ & $\begin{array}{c}-0.006 * * * \\
{[-8.979]}\end{array}$ & $\begin{array}{c}-1 \mathrm{e}^{-4} \\
{[-0.0207]}\end{array}$ & $\begin{array}{c}0.011 * * * \\
{[8.865]}\end{array}$ & $\begin{array}{c}-0.003 * * * \\
{[-7.471]}\end{array}$ \\
\hline MB & $\begin{array}{c}0.002 * * * \\
{[6.373]} \\
-\end{array}$ & $\begin{array}{c}0.002 * * * \\
{[6.282]}\end{array}$ & $\begin{array}{c}0.002 * * * \\
{[7.786]}\end{array}$ & $\begin{array}{c}0.002 * * * \\
{[5.428]}\end{array}$ & $\begin{array}{c}0.001 * * * \\
{[3.625]}\end{array}$ & $\begin{array}{c}3.9 \mathrm{e}^{-4} \\
{[1.618]}\end{array}$ & $\begin{array}{c}0.001 * * * \\
{[7.998]}\end{array}$ \\
\hline$R O A$ & $\begin{array}{c}0.146 * * * \\
{[-24.79]}\end{array}$ & $\begin{array}{c}-0.137 * * * \\
{[-23.25]}\end{array}$ & $\begin{array}{c}-0.124 * * * \\
{[-27.93]}\end{array}$ & $\begin{array}{c}-0.068 * * * \\
{[-6.486]}\end{array}$ & $\begin{array}{c}-0.186^{* * *} \\
{[-25.85]}\end{array}$ & $\begin{array}{c}-0.126^{* * *} \\
{[-23.69]}\end{array}$ & $\begin{array}{c}-0.174 * * * \\
{[-33.08]}\end{array}$ \\
\hline Leverage & $\begin{array}{c}-0.011 * * \\
{[-2.193]} \\
\end{array}$ & $\begin{array}{c}-0.006 \\
{[-1.170]}\end{array}$ & $\begin{array}{c}-0.011 * * * \\
{[-2.862]} \\
\end{array}$ & $\begin{array}{c}-0.005 \\
{[-0.726]}\end{array}$ & $\begin{array}{c}-0.013 * * \\
{[-2.044]}\end{array}$ & $\begin{array}{c}0.007 \\
{[1.063]}\end{array}$ & $\begin{array}{c}0.012 * * * \\
{[3.162]} \\
\end{array}$ \\
\hline $\begin{array}{l}\text { Industry Dum. } \\
\text { Year Dummies } \\
\text { Firm Dummies } \\
\text { Observations } \\
\text { R-squared }\end{array}$ & $\begin{array}{c}\text { Yes } \\
\text { Yes } \\
\text { No } \\
68678 \\
0.259\end{array}$ & $\begin{array}{c}\text { Yes } \\
\text { Yes } \\
\text { No } \\
68678 \\
0.275\end{array}$ & $\begin{array}{c}\text { Yes } \\
\text { Yes } \\
\text { No } \\
68678 \\
0.268\end{array}$ & $\begin{array}{c}\text { Yes } \\
\text { Yes } \\
\text { No } \\
32623 \\
0.228\end{array}$ & $\begin{array}{l}\text { Yes } \\
\text { Yes } \\
\text { No } \\
36055 \\
0.319\end{array}$ & $\begin{array}{l}\text { Yes } \\
\text { Yes } \\
\text { Yes } \\
68678 \\
0.101\end{array}$ & $\begin{array}{c}\text { Yes } \\
\text { Yes } \\
\text { No } \\
79755 \\
0.163\end{array}$ \\
\hline
\end{tabular}




\section{Table 6: Competition and Earnings Management Controlling for Firm-Level Corporate Governance Characteristics}

Model (1) examines the effect of board independence, calculated as the number of independent board members divided by total board of director memberships. Model (2) examines the effect of anti-takeover indexes as advanced by Gompers et al.(2003). Model (3) examines the role of CEO stock-option holdings, calculated as the total CEO stock options divided by total shares outstanding. Model (4) looks at the effect of share turnover, defined as total number of shares traded during the year divided by total shares outstanding. Model (5) looks at the institutional classifications of Bushee (1998), defined as short term volatile investors (Transient), indexing institutions (Indexer), and long-term dedicated institutions (Dedicated). DA denotes the absolute value of discretionary accruals calculated according to the modified Jones model, adjusted for the forward looking model of Dechow et al.(2003), adjusted for changes in cash according to Chan et al. (2002). Competition is the Herfindhal- Hirschman index of industry concentration multiplied by minus one. Standard control variables as per Table 5 are utilized but not reported (Mktval, ROA, Return, Leverage, Volatility MB). The time period is $1989-2006$, all variables are winsorized at $1 \%$ at each end. $* * *, * * *$ signify significance levels at $1 \%, 5 \%$, and $10 \%$, respectively

\begin{tabular}{|c|c|c|c|c|c|}
\hline VARIABLES & $\begin{array}{l}\text { (1) } \\
\text { DA }\end{array}$ & $\begin{array}{l}\text { (2) } \\
\text { DA }\end{array}$ & $\begin{array}{l}\text { (3) } \\
\text { DA }\end{array}$ & $\begin{array}{l}\text { (4) } \\
\text { DA }\end{array}$ & $\begin{array}{l}5) \\
D A\end{array}$ \\
\hline Competition & $\begin{array}{c}0.204 * * \\
{[1.970]}\end{array}$ & $\begin{array}{c}0.296 * * * \\
{[4.352]}\end{array}$ & $\begin{array}{c}0.239 * * * \\
{[2.925]}\end{array}$ & $\begin{array}{c}0.292 * * * \\
{[6.916]}\end{array}$ & $\begin{array}{c}0.231 * * \\
{[2.129]}\end{array}$ \\
\hline BIndependence & $\begin{array}{c}0.016 \\
{[1.390]}\end{array}$ & & & & $\begin{array}{c}0.024 * \\
{[1.866]}\end{array}$ \\
\hline Gompers & & $\begin{array}{c}7 e^{-4} \\
{[0.143]}\end{array}$ & & & $\begin{array}{c}8.7 \mathrm{e}^{-4} \\
{[1.153]}\end{array}$ \\
\hline StockOptions & & & $\begin{array}{c}-0.002 \\
{[-0.983]}\end{array}$ & & \\
\hline Turnover & & & & $\begin{array}{c}0.012 * * \\
{[8.090]}\end{array}$ & \\
\hline Dedicated & & & & & $\begin{array}{c}-0.013 \\
{[-0.726]}\end{array}$ \\
\hline Transient & & & & & $\begin{array}{c}0.064 * * * \\
{[3.551]}\end{array}$ \\
\hline Indexer & & & & & $\begin{array}{c}-0.038 * * * \\
{[-3.137]}\end{array}$ \\
\hline Industry Dummies & Yes & Yes & Yes & Yes & Yes \\
\hline Year Effects & Yes & Yes & Yes & Yes & Yes \\
\hline Observations & 11305 & 17783 & 16307 & 68586 & 9689 \\
\hline R-squared & 0.269 & 0.271 & 0.264 & 0.262 & 0.260 \\
\hline
\end{tabular}




\section{Table 7: Robustness Analysis Examining the Relationship between Competition and Earnings Manipulation}

Model (1) utilizes DD, as a dependent variable, while Models (2) and (3) utilize MBEAT and BEAT as dependent variables, respectively, Finally, Models (4) and (5) utilize DA as a dependent variable. $D D$ denotes the earnings quality measure of Dechow and Dichev (2002). MEET is a dummy variable equal to 1 if a firm just meets or beats consensus analyst forecasts, zero otherwise. $B E A T$ is a dummy variable equal to 1 if a firm meets or exceeds consensus analyst forecasts, zero otherwise. $D A$ denotes the absolute value of discretionary accruals calculated according to the modified Jones model, adjusted for the forward looking model of Dechow et al.(2003), adjusted for changes in cash according to Chan et al. (2002).

Competition is the Herfindhal- Hirschman index of industry concentration multiplied by minus one.

LogAnalyst is the number of analysts following the firm. Imports is the degree of import penetration (as a proxy for higher competition). Import Tariffs is the magnitude of import tariffs in the industry (as a proxy for lower less competition). Standard control variables as per Table 5 are utilized but not reported (Mktval, ROA, Return, Leverage, Volatility MB). The time period is $1989-2006$, all variables are winsorized at $1 \%$ at each end. $* * *, * * *$ signify significance levels at $1 \%, 5 \%$, and $10 \%$, respectively.

\begin{tabular}{|c|c|c|c|c|c|}
\hline VARIABLES & $\begin{array}{l}(1) \\
D D\end{array}$ & $\begin{array}{c}(2) \\
M E E T\end{array}$ & $\begin{array}{c}(3) \\
B E A T\end{array}$ & $\begin{array}{l}(4) \\
D A\end{array}$ & $\begin{array}{l}(5) \\
D A\end{array}$ \\
\hline Constant & $\begin{array}{c}0.058 * * * \\
{[4.139]}\end{array}$ & $\begin{array}{c}-2.778 * * * \\
{[-6.006]}\end{array}$ & $\begin{array}{c}-0.789 * * \\
{[-2.292]}\end{array}$ & $\begin{array}{c}0.137 * * * \\
{[11.32]}\end{array}$ & $\begin{array}{c}0.126^{* * * *} \\
{[14.51]}\end{array}$ \\
\hline Competition & $\begin{array}{c}0.339 * * * \\
{[5.708]}\end{array}$ & $\begin{array}{c}-0.079 \\
{[-0.111]}\end{array}$ & $\begin{array}{c}1.044 * * * \\
{[2.617]}\end{array}$ & & \\
\hline LogAnalyst & & $\begin{array}{c}0.329 * * * \\
{[9.460]}\end{array}$ & $\begin{array}{c}0.259 * * * \\
{[12.67]}\end{array}$ & & \\
\hline Imports & & & & $\begin{array}{c}5 \mathrm{e}^{-4 * *} \\
{[1.930]}\end{array}$ & \\
\hline Import Tariffs & & & & & $\begin{array}{c}-4.69 \mathrm{e}^{-4} * * * \\
{[-5.838]}\end{array}$ \\
\hline $\begin{array}{l}\text { Industry Dummies } \\
\text { Year Dummies } \\
\text { Observations } \\
\text { R-squared }\end{array}$ & $\begin{array}{c}\text { Yes } \\
\text { Yes } \\
46866 \\
0.423\end{array}$ & $\begin{array}{c}\text { Yes } \\
\text { Yes } \\
52532 \\
0.04\end{array}$ & $\begin{array}{c}\text { Yes } \\
\text { Yes } \\
52532 \\
0.06\end{array}$ & $\begin{array}{c}\text { Yes } \\
\text { Yes } \\
19138 \\
0.196\end{array}$ & $\begin{array}{c}\text { Yes } \\
\text { Yes } \\
19138 \\
0.197\end{array}$ \\
\hline
\end{tabular}


Figure 1: Illustration of which equilibrium is achieved as a function of $\pi_{L}^{1}-\pi_{H}^{1}$

\begin{tabular}{|c|c|c|}
\hline $\begin{array}{l}\text { Separating equilibrium } \\
\text { with no accounting } \\
\text { manipulation }\end{array}$ & No equilibrium & 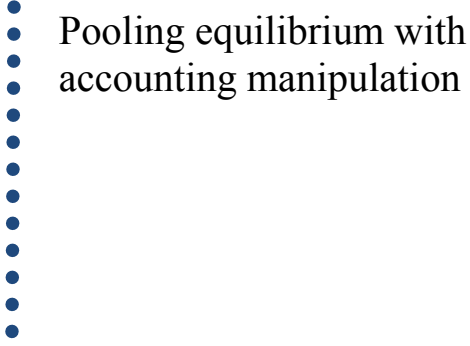 \\
\hline
\end{tabular}

Figure 1 illustrates how the probability of getting an equilibrium with or without earnings manipulation depends on the magnitude of $\pi_{L}^{1}-\pi_{H}^{1}$. For low levels of $\pi_{L}^{1}-\pi_{H}^{1}$ we get a separating equilibrium with no accounting manipulation, for intermediate levels we have no equilibrium while for large levels of $\pi_{L}^{1}-\pi_{H}^{1}$ the model predicts an equilibrium with accounting manipulation. 